\title{
SZUBSZONIKUS SZÉLCSATORNÁBAN KIALAKULÓ SEBESSÉGELOSZLÁS MÉRÉSE LDA TECHNIKA ALKALMAZÁSÁVAL
}

\section{A MEASUREMENT OF THE VELOCITY DISTRIBUTION IN A SUBSONIC WIND TUNNEL APPLYING LDA TECHNIQUE}

\author{
Dorogi Dániel $^{1}$, Bencs Péter ${ }^{2}$ \\ ${ }^{1}$ Miskolci Egyetem Gépészmérnöki és Informatikai Kar, Energetikai és Vegyipari \\ Gépészeti Intézet, Áramlás- és Hötechnikai Gépek Intézeti Tanszék, Cím: H-3515, \\ Miskolc, Miskolc-Egyetemváros; dorogiddaniel@gmail.com \\ ${ }^{I}$ Miskolci Egyetem Gépészmérnöki és Informatikai Kar, Energetikai és Vegyipari \\ Gépészeti Intézet, Áramlás-és Hötechnikai Gépek Intézeti Tanszék, H-3515 Miskolc- \\ Egyetemváros, Telefon: +3646565 154,arambp@uni-miskolc.hu
}

\begin{abstract}
There are several occasions when the properties of the flow are wanted to be investigated around the cross section of the wind tunnel. The first method which can be applied is PIV (Particle Image Velocimetry) which investigates the parameters of the flow in a discrete time. On the other hand the second type of the most popular techniques is LDA (Laser Doppler Anemometry) which can be used when the flow is wanted to be measured with respect to time. We used LDA method in a subsonic wind tunnel in order to investigate the velocity distribution in case of four different main velocities which can be modified by an axial fan. From the results conclusions will be drawn which will be used in further measurements.
\end{abstract}

Keywords: wind tunnel, $L D A$, velocity distribution, empirical density function

\section{Összefoglalás}

A müszaki gyakorlatban számtalanszor találkozhatunk olyan esettel, amikor egy áramlási folyamat jellemzőit az áramlás teljes keresztmetszetében szükséges vizsgálni. Erre a szakirodalom több lehetöséget is biztosít. Vannak olyan módszerek, amelyek segítségével a folyamatot egy adott időpillanatban tudjuk jellemezni (PIV), illetve olyan eljárások is, amelyek az áramlás paramétereinek időtől való függését kutatják. Erre kiváló példa az LDA (Laser Doppler Anemometry), amely a folyadékkal együtt mozgó részecskék mozgási jellemzőit beavatkozás mentesen követi le. Vizsgálataink során e mérési technikát alkalmaztuk a tanszéken lévő szubszonikus (zárt, hangsebesség alatti) szélcsatorna egy meghatározott keresztmetszetében kialakuló sebességeloszlás meghatározására négy különböző áramlási sebesség esetén, amelyet egy axiális ventilátorral változtattunk. A kapott eredményekböl következtetéseket vontunk le, amelyeket a későbbi méréseink során fogunk felhasználni.

Kulcsszavak: szélcsatorna, LDA, sebességeloszlás, empirikus sürüségfüggvény

\section{Bevezetés}

Az LDA technika egy olyan beavatkozás mentes mérést megvalósító lézeres eljárásmód, amely tulajdonképpen az áramlásba juttatott olajköd részecskék által okozott fényszórásból számítja vissza a közeg adott pontbeli áramlási sebességét. [1] 
Ezt a technikát mi egy szubszonikus (zárt, hangsebesség alatti) szélcsatornában alkalmaztuk, amelyben a levegö munkaközeg mozgatását egy axiális ventilátor végezte. A csatornában egy zsalurendszer is helyet foglalt, amelynek szerepe a sebesség szélesebb határok között való szabályozása. Elsődleges feladatunk az volt, hogy a szélcsatorna mérőterének egy általunk kiválasztott keresztmetszetében kimérjük a sebességprofilt négy különböző motorfrekvencia (a ventilátort hajtó motoré) mellett, nyitott és zárt zsaluk esetén egyaránt. Ebből meg tudjuk határozni, hogy átlagosan mekkora sebesség alakul ki az adott keresztmetszetben, illetve választ kapjunk a sebességeloszlás egyenletességére. A mérési felületet és a mérési pontok helyzetét (fekete pontok) az 1. ábra szemlélteti:

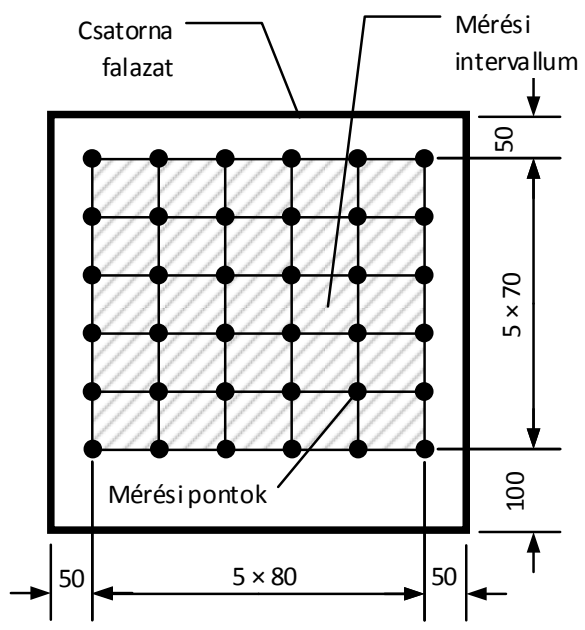

1. ábra. A mérési felület geometriai kialakítása

A méréseket úgy végeztük, hogy a berendezés a sebességértékeket két csatornán gyüjtötte, mintavételezett pontonként összesen 10000-10000 adatot.

\section{A mérési eredmények és kiérté- kelésük}

Az első kísérletek során kiderült, hogy a csatornában a domináns sebességi irány az $U$ komponens (a csatorna keresztmetszetére merőleges irány), amelyhez képest a $V$ komponens elhanyagolhatóan kicsiny. Így a kiértékelés során csak az $U$ sebességkomponenst vettük figyelembe. Az eloszlás meghatározásához először meg kellett vizsgálni a kapott adathalmazokat abból a szempontból, hogy mennyi hibás értéket tartalmaznak, majd ezeket kiszürni, ugyanis ellenkező esetben a valóságos sebességeloszlást torzíthatják. Ezt úgy tehetjük meg, hogy elkészítjük a mérési sorozat sürüségfüggvényét és megvizsgáljuk, hogy milyen intervallumon belül fordul elő a mért értékeknek legalább 95\%-a. Számításokkal alátámasztható, hogy nem minden mérési sorozat képvisel Gauss-eloszlást, ebből következően nem lehet erre alapozva számításokat végezni. A szakirodalom [2] ebben az esetben az empirikus sürüségfüggvény előállítását javasolja.

Az eljárás első lépése, hogy egy-egy mérési adatsort felosztjuk $k<n$ számú, $\Delta u$ szélességü csoportokra, amelyeket a középpontjukhoz tartozó $x_{f}$ mérési adattal jellemzünk, ahol $n$ jelöli a mérési sorozat elemszámát. Megvizsgálva, hogy az egyes csoportokba hány elem esik, majd ezt ábrázolva az intervallumszélesség függvényében, a relatív gyakorisági hisztogramot kapjuk. Ebből az empirikus sürüségfüggvény úgy készíthető el, ha a relatív gyakorisági hisztogram ordinátáját elosztjuk az adathalmaz elemszámával. Így tulajdonképpen a görbe alatti terület megegyezik annak a valószínüségével, hogy a mérési adatok a vizsgált intervallumba esnek-e. Az intervallum határait általában a szórás egész számú többszöröseként szokták megadni, ehhez viszont e mennyiséget definiálni szükséges: 


$$
s_{r}=\sqrt{\frac{1}{n} \cdot \sum_{i=1}^{k}\left(u_{r i}-\overline{u_{r}}\right)^{2} \cdot n_{r i}},
$$

ahol $u_{i}$ a mérési sorozat $i$-edik eleme, $\bar{u}_{r}$ a csoportosított adathalmaz átlaga, $n_{r i}$ pedig az $i$-edik csoportba tartozó adatok száma.

Kérdésként merült fel, hogy hány csoportra érdemes felosztani a teljes intervallumot. Ehhez készítettünk egy olyan számítást, amely azt mutatja be, hogy hogyan változik $s_{r}{ }^{2} / E_{r}{ }^{2}$ értéke a csoportszám növelése esetén, ahol $E_{r}$ a csoportosított mérési sorozat átlagos abszolút eltérése. E mennyiséget az alábbi összefüggés segítségével definiálhatjuk:

$$
E_{r}=\frac{1}{n} \cdot \sum_{i=1}^{k}\left|\mathrm{u}_{r i}-\overline{u_{r}}\right| \cdot n_{r i} .
$$

A 2. ábra e számítás eredményét szemlélteti egy példaként vett mérési sorozat esetében.

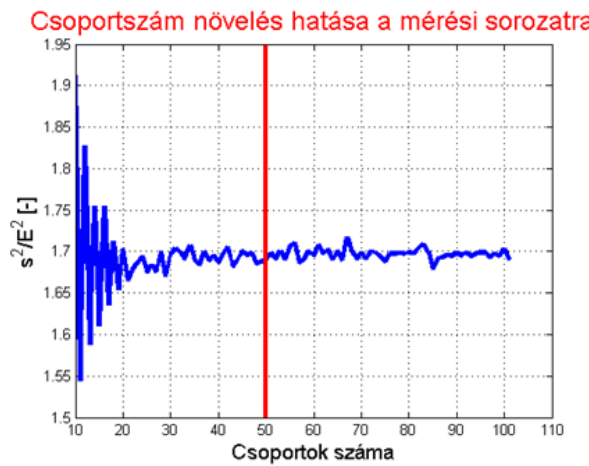

2. ábra $A$ csoportszám növelés hatása a mérési sorozatra

A 2. ábrán jól követhető, hogy az intervallumszélesség csökkentésének kis csoportszámok esetén igen nagy befolyása van, míg, ha $\Delta u$ értékét egy bizonyos érték alá visszük, akkor egyre kisebb befolyást tapasztalhatunk. Ebből következően a további számítások során a csoportok számát cél- szerü 30 fölé emelni, így ezt az értéket - a biztonság irányába haladva - a továbbiakban 50-re választottuk.

Ötven egyenlő részre osztott mérési intervallum esetén a példaként vizsgált adathalmaz empirikus sürüségfüggvénye a $\mathbf{3}$. ábrán látható.

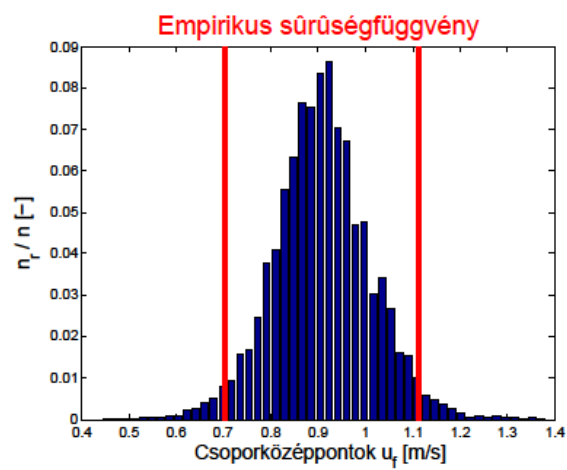

3. ábra $A$ mérési sorozat empirikus sürüségfüggvénye 50 részre osztott intervallum esetén

Amennyiben azt szeretnénk megtudni, hogy a mérési adatok mekkora valószínüséggel tartózkodnak a várható érték körüli $\left(x_{1} ; x_{k}\right)$ intervallumban, akkor azt az alábbi összefüggés felhasználásával számíthatjuk ki [3]:

$$
P\left(\mathrm{x}_{1} ; \mathrm{x}_{k}\right)=\sum_{i=1}^{k} f\left(\mathrm{x}_{r i}\right) \cdot \Delta x_{i} .
$$

A (3) összefüggést példánkban felhasználva, annak valószínűsége, hogy a mérési adatok az $\bar{x} \pm 2 \cdot s$ intervallumba esnek az empirikus sürüségfüggvény alapján:

$$
P(\bar{x}-2 s ; \bar{x}+2 s) \cong 94,5990 \% .
$$

Mivel a mérési adatok nagyjából 95\%os valószínüséggel esnek az imént vizsgált intervallumba, így mondhatjuk azt, hogy az ezen kívül eső adatok hibásak. Ezeket kiszürjük és az új adathalmazokra kiszámítjuk a sebességek átlagos értékeit. A 4. ábrán a 
$30 \mathrm{~Hz}-\mathrm{es}$ motorfrekvencia esetén, nyitott zsaluk mellett mért, és a fentiek szerint feldolgozott sebességeloszlás látható.

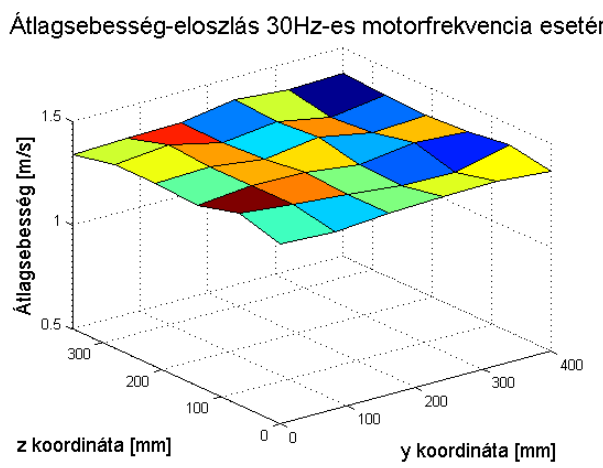

4. ábra Átlagsebesség-eloszlás $30 \mathrm{~Hz}$-es motorfrekvencia esetén

A kapott eloszlásokból integrál-középérték segítségével kiszámítjuk állandó motorfrekvencia esetén egy felületre vett átlagsebességet az (5) kifejezés szerint.

$$
\mathrm{U}_{a t t i}\left(\mathrm{f}_{i}\right)=\frac{1}{a \cdot b} \cdot \int_{z=z_{\min }}^{z_{\max }} \int_{y=y_{\min }}^{y_{\max }} u(\mathrm{y}, \mathrm{z}) \mathrm{dydz}
$$

ahol $a=y_{\max }-y_{\min }$ és $b=z_{\max }-z_{\min }$.

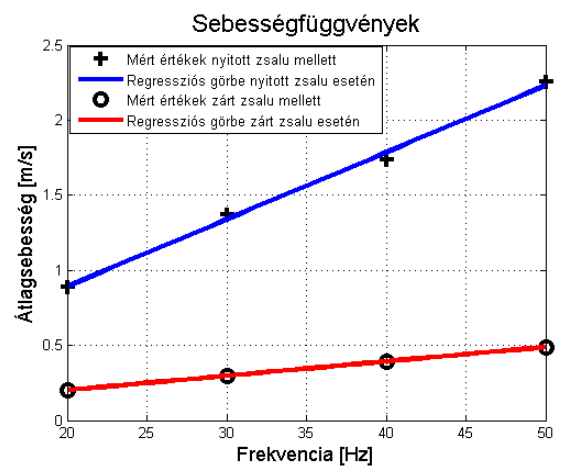

5. ábra Sebesség-frekvencia görbék
Amennyiben ezt minden vizsgált frekvencia esetén elvégezzük és ábrázoljuk a frekvencia függvényében, akkor az 5 . ábra szerinti pontokat kapjuk zárt és nyitott zsaluk esetén.

\section{Következtetések}

A szélcsatornát a továbbiakban egy prizmatikusnak tekinthető körhenger körüli áramlás vizsgálatakor kívánjuk alkalmazni. A mérések során vizsgálataink alapján a motorfrekvencia és az áramlási átlagsebesség között a $(6,7)$ összefüggések segítségével teremthetünk kapcsolatot. A vizsgálatokból származó sebesség-frekvencia görbére ugyanis az 5. ábrából látható módon egy-egy regressziós egyenes fektethetö, amelyeknek egyenletei:

$$
\begin{aligned}
& \left.\mathrm{U}_{\text {att }}\right|_{\text {nyitott }}(\mathrm{f})=0,0445 \cdot f+0,0023, \\
& \left.\mathrm{U}_{\text {att }}\right|_{\text {nyitott }}(\mathrm{f})=0,0096 \cdot f+0,0070 .
\end{aligned}
$$

A $(6,7)$ kifejezések segítségével könynyen kiszámítható az a frekvencia érték, amelyet be kell állítani ahhoz, hogy a kívánt áramlási sebességet elóállítsuk.

\section{Szakirodalmi hivatkozások}

[1] Dr. Paripás Béla, Dr. Szabó Szilárd, Kocsisné Dr. Baán Mária, Dr. Tolvaj Béláné, Bencs Péter: Lézeres mérési- és megmunkálási eljárások a gépészetben, Nemzeti Tankönyvkiadó, Budapest, 2009, 147-153. oldal.

[2] Váradiné dr. Szarka A., Dr. Hegedűs J., Bátorfi R., Unhauzer A.: Méréstechnika, Miskolci Egyetem, Miskolc, 2007, 11-60. oldal. 